\title{
Production line intended for implementation of innovative technologies of cleaning and frac- tionation of raw coriander
}

\author{
Sergey Kyazimovich Mustafayev \\ Tatyana Vladimirovna Pelipenko \\ Alexander Nikolayevich Drozdov \\ Federal State Budgetary Educational Institution of Higher \\ Education \\ Krasnodar, Russia \\ Kuban State Technological University \\ mustafaev_sk@mail.ru
}

\author{
Kalienko Ekaterina Aleksandrovna \\ OOO Rasma \\ Krasnodar, Russia \\ kalienco@rambler.ru
}

\begin{abstract}
Raw coriander, which is mainly produced by the Russian Federation, contains 1.62-2.40 \% of essential oil and up to $28.5 \%$ of fatty oil. Essential oil is a product of coriander seeds processing, in which the content of the most valuable component linalyl ester (monoterpene monoatomic trisubstituted carbinol with the scent of May lily) should be no less than $65 \%$. Geraniol and geranyl acetate also belong to valuable components of coriander essential oil, while camphor is undesirable. Anatomic morphological structure of coriander fruits, which consist of two mericarps and essential-oil receptacles on their inner surface, leads to their splitting during the transportation and post- harvest losses of essential oil amount to $23.4 \%$. The most rational operating modes of basic equipment, a separator, have been established for the previously developed method of separation of raw coriander and simultaneous fractionation into whole and split fruits with the help of a sieve with a mesh-size $2 \times 20 \mathrm{~mm}$, with primary processing of split fruits and the production of more valuable essential oils. The determined operational modes are the following: the vibration frequency of a sieve box which is 400 vibrations/min, the vibrational amplitude of the sieve box is $8 \mathrm{~mm}$, the sieve inclination angle is 8 degrees, a layer of raw materials is $5 \mathrm{~mm}$ tick. The principal flow sheet of production line for implementation of innovative technologies in industry has been developed where Russian equipment is used. The developed innovative technology and the principal flow sheet of the production line allow dividing initial raw coriander into two fractions of whole and split fruits with efficiency up to $91,8 \%$, which improves the cleaning efficiency of raw coriander from foreign impurities to $96.8 \%$ in the fraction of whole fruits and up to $73.8 \%$ in the fraction of split fruits, while in generally accepted technology the cleaning efficiency is from 36 to $51 \%$ for overall raw materials. That allows producing essential oils from the fraction of split fruits with higher content of valuable components.
\end{abstract}

Key words-raw coriander, foreign impurities, mericarps, essential oil, fractionation, production line.

\section{INTRODUCTION}

The Russian Federation is the main producer of raw coriander, which is processed to obtain essential and fatty oils, as well as fodder products [1, 2]. Basic coriander varieties released in the Russian Federation contain 1.62-2.40\% of essential oils and up to $28.5 \%$ of fatty oils in conversion to absolute dry substance [3]. Essential oil is a main target product in the processing of raw coriander which demand is stable high and has a tendency for growth [4, 5]. In this connection new varieties are constantly developed to increase its content. For example, in the new variety Aydar the mass fraction of essential oil is from $2.67 \%$ to $3.87 \%$ [6], whereas the content of essential oil in the perspective variety EVA-1 is 4.5-4.8\% [7]. The composition of coriander essential oil includes about two dozen of components, the most valuable component is linalyl ester (3.7-dimethyl -1,6-octadiene -3ol) - a monoterpene monoatomic trisubstituted carbinol with the scent of May lily , but camphor is undesirable [2, 8, 9]. According to valid Russian Standard GOST ISO 3516, the mass fraction of linalyl ester must be no less than $65 \%$, while the mass fraction of camphor must be no more than $4 \%$.

In its anatomic morphological structure, a coriander fruits consist of two mericarps and essential-oil receptacles located inside on the surface of each mericarp, which is a crescent shaped structure with thin porous husk containing essential oil [3]. As a result of this structure coriander fruits are split into two halves during transportation, post - harvest handling and so on, therefore, there is a considerable amount of split fruitsmericarps in husks and mericarps without husks in raw coriander [8]. When coriander fruits are split, oil receptacles can be seen on the surface of mericarps. Their walls are easily damaged upon contact with adjacent seeds and oil goes onto the surface and evaporates [2, 8]. The extend of losses depends on the amount of damaged receptacles, the time and intensity of raw materials movements, temperature and the range of other conditions [10]. According to the research recently carried out, the mass fraction of split fruits in raw coriander can reach $28 \%$, when losses of essential oil are $23.4 \%$ [11]. By contrast, the essential oil made of split fruits has more valuable components - linalyl ester, geraniol, geranyl acetate in comparison with the essential oil made of whole fruits. In this connection, one must admit it is expedient to separate split fruits from whole ones (fractionation). Some authors also recognize the primary processing of split fruits as 
a perspective direction $[2,8,10,12]$. However, according to the conventional technology of raw coriander processing, aimed at obtaining essential and fatty oils, split fruits are not separated after cleaning. They are stored together with whole fruits and then processed [3].

At present a new method of step-by-steep cleaning of raw coriander from foreign impurities has been developed with simultaneous fractionation into whole and split fruits [13]. The method includes cleaning of raw coriander from large foreign impurities and fractionation into whole and split fruits. Hard separable and small foreign impurities are removed at the first stage of processing, while split fruits are subsequently separated from foreign impurities at the second stage. A sieve with a mesh $5 \mathrm{~mm}$ in diameter is used to separate modern raw coriander from large foreign impurities [3]. For fractionation into whole and split fruits it is reasonable to use a sieve with rectangular openings $2 \times 20 \mathrm{~mm}$ in diameter. At the second stage when hard-separable foreign impurities are removed the sieve with a mesh $4 \mathrm{~mm}$ in diameter is used, while small foreign impurities are removed using the sieve with a mesh size $1.5 \mathrm{~mm}$ in diameter [3]. It is recommended to process the separated fraction first, and to use the obtained oil for the enrichment of essential oil made of whole fruits [13]. In order to use the developed method of cleaning and fractionation of raw coriander in industry, it is necessary to estimate optimal conditions of cleaning and fractionation of industrial raw coriander and to create a principal flow sheet of proper production line, which is the aim of this work.

\section{METHOD}

The research object is a united specimen from samples of industrial raw materials of coriander delivered to a processing enterprise (OOO «Fort», Ust-Labinsk) in 2014. An average specimen was selected from the united sample of industrial raw coriander [14] and its fractional composition was determined. Thereafter, whole fruits of coriander, mericarps in husks and mericarps without husks were selected.

Various factors influence the efficiency of sieve separation (fractionation) in production: the size of a sieve mesh, materials and the construction of a sieve, dimensions, shape of a sieve channel and the method of sieve separation, kinematic mode of a working unit $[15,16]$.Therefore, optimal parameters of separation of raw coriander on a stand separator were determined under laboratory conditions, which have the following specification figures : the type of actuators is from an electric motor, the vibrator is eccentric with adjustable vibration amplitudes, the working width of the sieve is $0.24 \mathrm{~m}$, the sieve length is $0.7 \mathrm{~m}$, its total square is $0.168 \mathrm{~m} 2$. It is possible to change the vibration frequency, a load per unit, the sieve inclination angle and the supply speed of materials. The sieve with a mesh $5 \mathrm{~mm}$ in diameter was used to determine optimal parameters of separation for raw coriander from large foreign impurities [3]. In order to separate whole fruits, the sieve with dimensions $2 \times 20 \mathrm{~mm}$ was used, while the sieve with a mesh $4 \mathrm{~mm}$ in diameter was used to separate fractions of split fruits from hard-separable foreign impurities and the sieve with a mesh $1.5 \mathrm{~mm}$ in diameter was used to separate small foreign impurities.
Four factors were studied at two levels: the thickness of a layer of raw materials, the sieve inclination angle, vibrational amplitude, and vibration frequency. Measurements were performed by sifting industrial raw coriander with mass fraction of moisture no more than $12 \%$ when rectilinear vibration sieve was inclined.

The coefficient of fraction extraction factor of split fruits was used as the main response function (the parameter of optimization), or the fractionating efficiency $\mathrm{E},(\%)$. The main parameter of optimization was defined in accordance with the following formula [15].

$$
\mathrm{E}=\frac{\mathrm{A}}{\mathrm{B}} \cdot 100 \%
$$

where $\mathrm{A}$ is the mass of the separated fraction of split fruits.

$\mathrm{B}$ is the mass of fraction of spit fruits in the initial mixture which can be separated by above mentioned method.

In order to determine the design capacity of the separator, weight per unit area, $\mathrm{kg}(\mathrm{h}-\mathrm{cm})$ per $10 \mathrm{~mm}$ of sieve width was applied. [17].

For additional data a new indicator was introduced which characterizes sieve clogging. The sieve clogging index $\mathrm{K}$ was defined as the ratio of the area of clogged sieve mesh of to the total area of mesh F0 in accordance using the equation:

$$
\mathrm{K}=\frac{P}{F_{\mathrm{a}}} \cdot 100 \% \text {, }
$$

where $F$ is the area of clogged mesh of the sieve, $2 \mathrm{~cm}$;

$$
F_{0} \text { is the total area of sieve mesh, } 2 \mathrm{~cm} \text {. }
$$

The values of factors with the highest efficiency and minimal sieve clogging were recognized as optimal parameters.

\section{RESULTS AND DISCUSSION}

A sample of industrial raw coriander was separated from large foreign impurities on a sieve with a mesh $5 \mathrm{~mm}$ in diameter in accordance with recommendations used nowadays for technological modes of separation [3], and then its fractional composition was defined.

The fractional composition of a sample of industrial raw coriander used in tests is presented in Table 1.

TABLE I. THE COMPOSITION OF INDUSTRIAL RAW CORIANDER

\begin{tabular}{|l|c|}
\hline \multicolumn{1}{|c|}{ Name of fraction } & Mass fraction, \% \\
\hline Whole fruits & 62.7 \\
Whole fruits with diameter less than $2 \mathrm{~mm}$ & 4.6 \\
Mericarps in husks & 11.8 \\
Foreign impurities of the given plant & 10.4 \\
Foreign impurities, including & 10.5 \\
-equal in size with raw materials being separated and & 4.0 \\
hard-separable & \\
- small foreign impurities separated through the sieve & 6.5 \\
with a mesh 1.2 mm in diameter & \\
\hline
\end{tabular}

The data in the table above show that the fraction of mericarps includes mericarps in husks and ethereal oil impurities, which 
in their turn, consist of mericarps without husks (kernels), small immature, smashed and discolored to black fruits. There can be a part of foreign impurities remained after separation equal in size to main components of the fraction of split fruits.

It is well-known that machines with flat sieves with circular forward and backward and forward motion are used to size grade industrial seed mixture by thickness [15]. Main parameters of fractionation were defined on a test bed separator with backward and forward motion of sieves.

The planning matrix and results of research on separation industrial raw coriander into fractions of whole and split fruits are presented in Table 2.

TABLE II. THE PLANNING MATRIX AND RESEARCH RESULTS

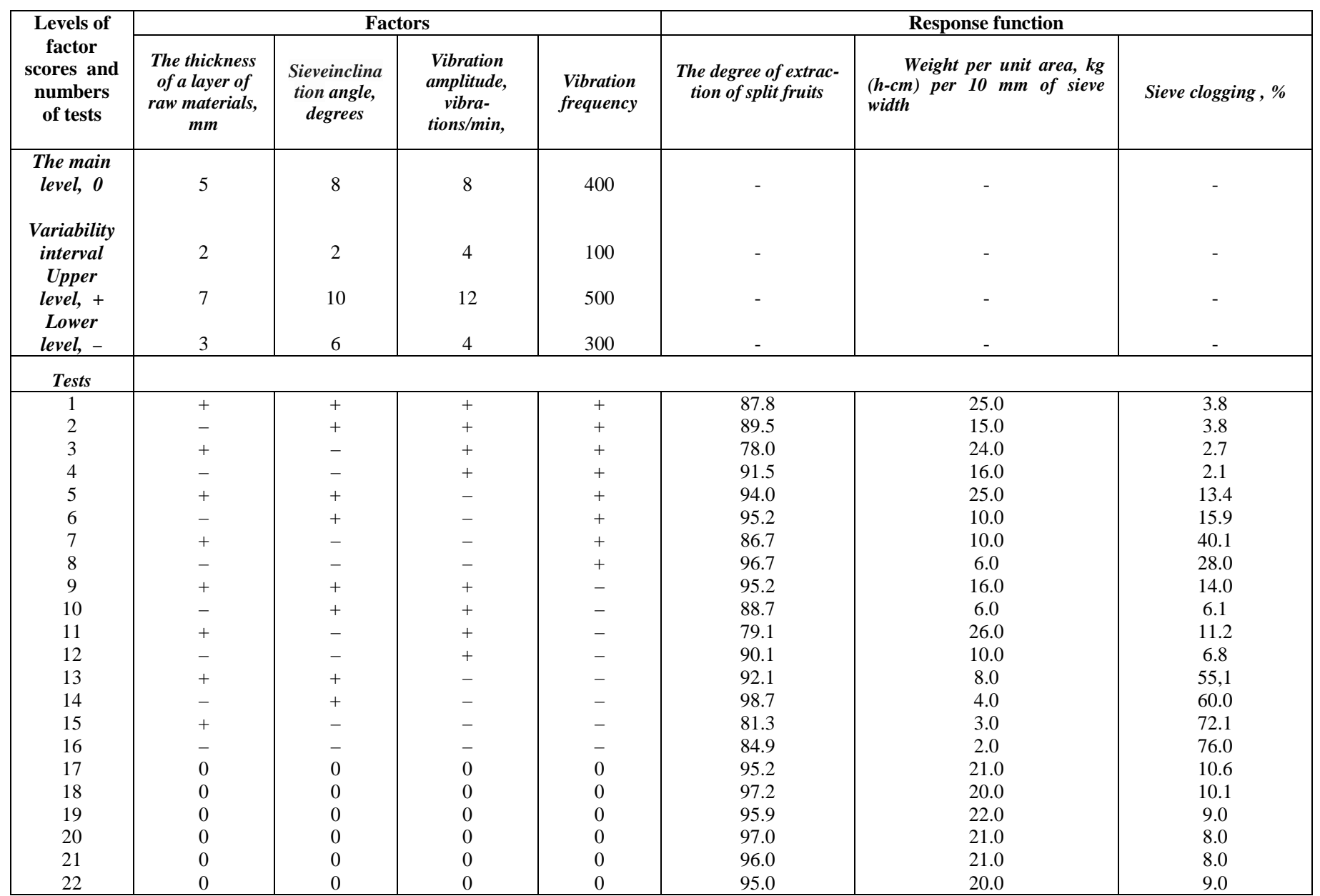

The analysis of results of complete factorial experiment has shown that the mathematical description of separation process with beta coefficients is inexpedient, since at the basic level of values of factors under examination high values of optimization parameters were obtained in experiments 17-22, which is sufficient to recommend them for production.

In these experiments the factors under examination had the following values: the vibration frequency of the sieve box was 400 vibrations per minute, the vibrational amplitude of the sieve box was $8 \mathrm{~mm}$, the sieve inclination angle is 8 degrees, a layer of raw materials is $5 \mathrm{~mm}$ tick. In this regard, the following average values of response functions were obtained: the coefficient of fraction extraction factor of split fruits was 96.1
$\%$; weight per unit area, $\mathrm{kg}(\mathrm{h}-\mathrm{cm})$ per $10 \mathrm{~mm}$ of sieve width was 21 kilos ( $\mathrm{cm} /$ hour), sieve clogging was $9.1 \%$. .

After establishing optimal parameters of fractionation, fractions of whole and split fruits were obtained; their component composition is presented in Table 3. 
TABLE III. COMPONENT COMPOSITION OF SEPARATED CORIANDER FRACTIONS

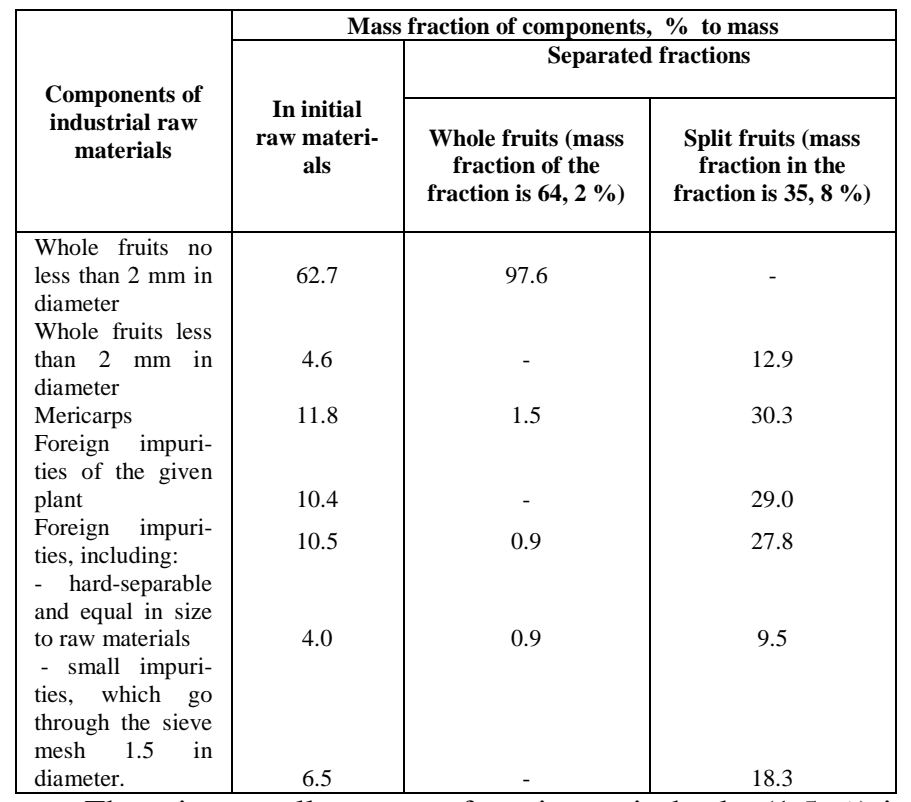

There is a small amount of mericarps in husks $(1.5 \%)$ in the fraction of whole fruits, which is $8.2 \%$ from the content of initial raw materials. Hence, the efficiency of fractionation taken into account mericarps in husks is $91.8 \%$.

Foreign impurities account $0.9 \%$ in the fraction of whole fruits which is $5.5 \%$ from the content of initial raw materials. Hence, the efficiency of fractionation taken into account foreign impurities is $94.5 \%$. The study of component composition of the fraction of whole fruits separated on the above mentioned sieves has shown the availability of mericarp husks which belong to organic foreign impurities according to valid Russian Standard GOST 17081. Husks are separated by air flow which enables one to increase the separating efficiency of the fraction up to $96.3 \%$.

It should be noted, the content of foreign impurities in the fraction of split fruits is high, which proves the expediency of its further cleaning. The cleaning of the fractions of split fruits has been tested on a stand separator in accordance with generally accepted technology of cleaning raw coriander including separation on sieves with mesh $4 \mathrm{~mm}$ and $1.5 \mathrm{~mm}$ in diameter [3].

The separation of the fraction of split fruits carried out in laboratory conditions, using the above mentioned sieves, has shown that the efficiency of separation from foreign impurities in the fraction of split fruits is $61.4 \%$. The research of the component composition of the given fraction has shown a big amount of light impurities (parts of husks, small seeds of weeds, and so on). Separation of such impurities in the airflow enables to increase the separating efficiency of the fraction from foreign impurities up to $73.8 \%$.

\section{CONCLUSION}

As the result of the carried out research the innovative technology of step-by-step cleaning of modern raw coriander from foreign impurities and simultaneous fractionation into whole and split fruits which includes the most rational operational modes of a separator.

In order to use the developed innovative technology in industry the principal flow sheet of the production line of separation and fractionation of raw coriander has been created which includes the most widespread equipment made in the Russian Federation. The principal flow sheet of the production line of separation and fractionation of raw coriander is presented in Figure 1.

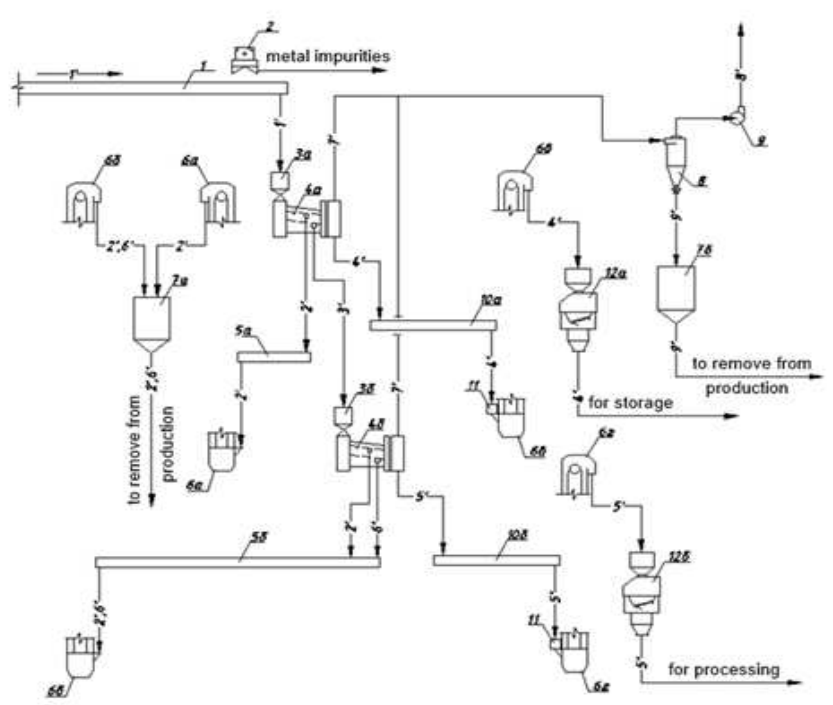

Fig. 1. Technological flow sheet of the production line of cleaning and fractionation of raw coriander: 1 - belt conveyer, 2 - magnet separator; $3 \mathrm{a}, \mathrm{b}-$ overhead separating hopper; 4a,b - separator A1-BIS-100; 5a,b - screw conveyer; 6a,b, c, d - bucket elevator; 7a,b - hopper of rubbish disposal ; 8 cyclone separator, 9 - ventilator; 10a,b - chain- conveyor ; 11 - magnet separator; $12 \mathrm{a}, \mathrm{b}$ - scales ND-500; 1 ' - raw coriander; 2 ' - large foreign impurities; $3^{\prime}-$ the fraction of split weedy fruits; $4^{\prime}-$ the fraction of clean whole fruits; $5^{\prime}$ - the fraction of clean split fruits; $6^{\prime}$ - small foreign impurities; $7^{\prime}-$ the air flow with light foreign impurities; 8' - clean air into atmosphere; 9' - light foreign impurities.

The presented principal flow sheet of the production line includes the following stages of the technological process of after-harvesting handling of industrial raw coriander:

- raw materials delivered for processing are cleaned from large foreign impurities intended to be removed;

-raw materials separated from large foreign impurities are fractionated into the fraction of whole fruits and the fraction of split fruits, including hard-separable and small foreign impurities;

- the fraction of whole fruits is separated from light impurities and sent for storage;

- the fraction of split fruits is separated from small and light foreign impurities and sent to be processed without any intermediate storage.

For implementation in industry, the developed innovative technology and the principal technological flow sheet of the production line have the following advantages in comparison with generally accepted technologies and lines: 
- they enable to separate the initial raw materials into two fractions of whole and split fruits with different working quality with efficiency up to $91.8 \%$, which lays the groundwork to further streamline the process of their storage and processing, to reduce losses of coriander essential and fatty oils in production;

- they improve the cleaning efficiency of raw coriander from foreign impurities to $96.8 \%$ in the fraction of whole fruits and up to $73.8 \%$ in the fraction of split fruits, while in generally accepted technology the cleaning efficiency is from 36 to $51 \%$ for overall raw materials.

- enable one to produce essential oil from the fraction of split fruits with higher content of valuable components (linalyl ester, geraniol, geranyl acetate linalyl ester, geraniol, geranyl acetate );

\section{References}

[1] Koriandr.

$$
\text { from }
$$

http://www.sit.sintextc.com $/$ modules.php?file $=$ article $\&$ name $=$ News $\&$ op $=$ modload $\&$ sid $=2$ (data obrashcheniya 06.06.2015).

[2] N.A.Turysheva, Uchebnoe posobie po tovarovedeniyu ehfirnomaslichnogo syr'ya, Krasnodar: Izd. KubGTU, 1989.

[3] V.E. Tarasov, Tekhnologiya ehfirnyh masel i fitopreparatov. Krasnodar: Izd. FGBOU VPO "KubGTU”, 2013.

[4] J. E. "Simon, Essential oils and culinary herbs", in New Crops. Proceed-ings of the first national symposium „New crops: research, development, economics“, Indian-apolis, Indiana, USA, 23-26 October 1988. (Ed/ by J. Janick and J.E. Simon). Timber Press, Portland, 1990, pp. $472-483$.

[5] A. Deiderichsen, "Coriander Coriandrum sativum L.", Promoting the conservation and use of underutilized and neglected crops, Rome, IPGRI, 1996, p. 83.
[6] Koriandr posevnoj. http://www.lana-pav.com/koriandr-posevnoj.html (data obrashcheniya 16.07.2015).

[7] Maslichnye kul'tury. Nauchno-tekhnicheskij byulleten' Vserossijskogo nauchno-issledovatel'skogo instituta maslichnyh kul'tur, vyp. 2 (135), 2006.

[8] F. S. Tanasienko, EHfirnye masla. Soderzhanie i sostav v rasteniyah. Kiev: Naukova dumka, 1985.

[9] S. A. Vojtkevich, EHfirnye masla dlya parfyumerii i aromaterapii. Moskva: Pishchevaya promyshlennost', 2001.

[10] A.F Polyakov, N.A. Turysheva, M.M. Saad, A.P. Usov, "Izuchenie raskalyvaemosti plodov koriandra", Izv. Vuzov, Pishchevaya tekhnologiya, vol. 5, 1978, p. 136-138.

[11] T.V. Pelipenko, S.K. Mustafaev, A.P. Usov, E.A. Kalienko, "Vliyanie frakcionnogo sostava koriandra na ego tekhnologicheskie svojstva", Politematicheskij setevoj ehlektronnyj nauchnyj zhurnal Kubanskogo gosudarstvennogo agrarnogo universiteta, vol. 113, 2015, p. 105-114.

[12] N. G. Ermol'eva, Kolichestvennye i kachestvennye izmeneniya plodov koriandra pri sozrevanii na rastenii i dozrevanii. Candidate dissertation. Krasnodar, 1985.

[13] S.K.Mustafaev, T.V. Pelipenko, A.P. Usov, E.A. Kalienko, "Innovations in Post-Harvest Handling of Coriander", International Journal of Pharmacy and Technology, Vol. 8, 2016, pp. 27334-27350.

[14] K.G. Persidskaya, A.P. CHipiga, Spravochnik dlya rabotnikov laboratorij ehfirnomaslichnyh predpriyatij. Moskva: Lyogkaya i pishchevaya promyshlennost', 1981.

[15] L.A Glebov, A.B. Demskij, V.F. Veden'ev, M.M. Temirov, YU. M. Ogurcov, Tekhnologicheskoe oborudovanie predpriyatij otrasli (zernopererabatyvayushchie predpriyatiya). Moskva, M.: DeLiprint, 2006.

[16] A.E. YUkish, O.A. Il'ina, Tekhnika i tekhnologiya hraneniya zerna. Moskva: DeLiprint, 2009.

[17] Vyrashchivanie koriandra, fromURL/http: fermeru.info/koriandrtexnologiya-vozdelyvaniya. (data obrashcheniya 15.05 .2015 ). 